Roden, J. S. and R.W. PEARCy (1993): The effect of flutter on the temperature of poplar leaves and its implications for carbon gain. Plant Cell Environment 16: 571-577.

Safou-Matondo, R., P. Deleporte, J. Laclau and J. Bouillet (2005): Hybrid and clonal variability of nutrient content and nutrient use efficiency in Eucalyptus stands in Congo. Forest Ecology and Management 210: 193-204.

Stanton, B. J., M. J. Serapiglia and L. B. Smart (2014): The Domestication and Conservation of Populus and Salix Genetic Resources. pp. 124-200. In: Poplars and Willows, Trees for Society and the Environment, edited by: IsEBrands, J. G. and J. Richardson, Published by FAO and CAB International, UK.

Tullus, A., L. RYTter, T. Tullus, M. Weih and H. Tullus (2012): Short-rotation forestry with hybrid aspen (Populus tremula L. $\times$ P. tremuloides Michx.) in Northern Europe. Scandinavian Journal of Forest Research 27: 10-29.
Tullus, A., H. Tullus, T. SoO and L. PÄRN (2009): Above-ground biomass characteristics of young hybrid aspen (Populus tremula L. $\times$ P. tremuloides Michx.) plantations on former agricultural land in Estonia. Biomass and Bioenergy 33: $1617-1625$.

Vinocur, A. and A. Altman (2005): Recent advances in engineering plant tolerance to abiotic stress: achievements and limitations. Current Opinion on Biotechnology 16: 123-132.

YAdAV, S. S., R. J. RedDEN, J. L. HATField, H. LotzeCAMPen, A. E. Hall and M. YADAV (2011): Crop Adaptation to Climate Change. Wiley-Blackwell, UK.

Yin, C.Y., B. L. DuAn, X. Wang and C.Y. Li (2004): Morphological and physiological responses of two contrasting Poplar species to drought stress and exogenous abscisic acid application. Plant Science 167: 1091-1097.

\title{
Mating system variation among populations, individuals and within and among fruits in Bertholletia excelsa
}

\author{
By L.H. O. WAdT ${ }^{1)}$, A. B. Baldoni ${ }^{2)}$, V.S. Silva ${ }^{3)}$, T. CAmpos $^{4)}$, K. Martins' ${ }^{5)}$, V.C. R. Azevedo ${ }^{6)}$, \\ L. R. MATA ${ }^{6)}$, A. A. Botin ${ }^{7)}$, E. S. S. Hoogerheide ${ }^{2)}$, H. Tonini ${ }^{2)}$ and A. M. SEBbenN ${ }^{8, *}$ )
}

(Received $5^{\text {th }}$ November 2015)

\begin{abstract}
The aim of this study was to investigate variation in mating system among three Brazilian Amazon populations of the tree Bertholletia excelsa with different levels of anthropogenic

\footnotetext{
1) Empresa Brasileira de Pesquisa Agropecuária (Embrapa), Embrapa Rondônia, BR $364 \mathrm{Km}$ 5,5. CEP 76.815-800, Porto Velho, RO, Brazil.

2) Empresa Brasileira de Pesquisa Agropecuária (Embrapa), Embrapa Agrossilvipastoril, Rodovia dos Pioneiros MT-222, Km 2,5. CEP 78550-970, Sinop, MT, Brazil.

3) Universidade Federal do Acre, Mestranda do Programa Ciência, Inovação e Tecnologia para a Amazônia, BR-364 Km 04, CP 500. CEP 69920-900, Rio Branco, AC, Brazil.

4) Empresa Brasileira de Pesquisa Agropecuária (Embrapa), Embrapa Acre, BR 364 Km 14. CEP 69908970, Rio Branco, AC, Brazil.

5) Universidade Federal de São Carlos, CCHB/Campus Sorocaba, Departamento de Biologia, Rodovia João Leme dos Santos (SP-264), Km 110. CEP 18052-780, Sorocaba, SP, Brazil.
}

interventions. We collected open-pollinated seeds from one natural population, remnant trees dispersed in a pasture, and trees from a plantation. Outcrossing rate not varied among the populations and indicates that all seeds were originated from outcrossing $\left(t_{m}=1.0\right)$. Mating among relatives was significant higher in the plantation than forest and pasture populations, probably due the fact that many trees are related in the plantation. Correlated mating was significantly higher in pasture $\left(r_{p}=0.47\right)$ and plantation $\left(r_{p}=0.51\right)$ than in the natural

\footnotetext{
6) Empresa Brasileira de Pesquisa Agropecuária (Embrapa), Cenargen, Parque Estação Biológica, PqEB, Av. W5 Norte (final). CEP 70770-917, Brasília, DF, Brazil.

$\left.{ }^{7}\right)$ Universidade Federal de Mato Grosso (UFMT), CEP 78550-000, Sinop, MT, Brazil.

8) Instituto Florestal de São Paulo, Estação Experimental de Tupi, Rodovia Luiz de Queiroz, km 149,5, CP 339, CEP 13400-970, Piracicaba, SP, Brazil.

*) Corresponding author: AlEXANDRE SEBBENN. E-Mail: alexandresebbenn@yahoo.com.br
} 
population $\left(r_{p}=0.22\right)$, suggesting that trees in natural population are pollinated by a higher number of pollen donors. The paternity correlation was significantly higher within $\left(r_{p(w)}=0.41\right)$ than among fruits $\left(r_{p(a)}=0.18\right)$, showing a higher probability to find full-sibs within than among fruits. The fixation index was generally lower in seed trees than in their seedlings, suggesting selection for heterozygous individuals from seedling to adult stages. Progeny arrays collected from the natural population had a lower proportion of pairwise full-sibs than in pasture and plantation and higher variance effective size (2.75) than trees in pasture (2.15) and plantations (2.22). Results highlight that seed collections for conservation, breeding and reforestation programs preferentially should be carried out in natural populations due low proportion highest variance effective size within progeny.

Key words: Brazil nut tree; Brazilian Amazon; conservation genetics; Lecythidaceae; microsatellite markers; population genetics; tropical tree species.

\section{Introduction}

The mating system is a key factor shaping the distribution of genetic variability in tree populations, since it determines how alleles are transmitted from one generation to another through reproduction. Mating systems are influenced by both genetic and environmental factors (KALISZ et al., 2004; GooDwILLIE et al., 2005; Good-Avila et al., 2008; Feres et al., 2012). Genetic factors are the sexual system, self-incompatibility, heterosis and inbreeding depression. Environmental factors are those affecting the behavior of pollination vectors, such as population density, distance between conspecifics, humidity, wind, and temperature (Millar et al., 2000; Fuchs et al., 2003). These both factors may affect outcrossing rates and correlated matings (DEGEN and SEBBENN, 2014).

Also, human disturbances such as habitat fragmentation and logging may affect mating systems by reducing the number of reproductive trees and increasing the distance between conspecifics. All these disturbances affect the amount and behavior of pollen vectors with consequences on the mating system (FUCHS et al., 2003; Lowe et al., 2005; AGUILAR et al., 2008; LACERDA et al., 2008; ARRUDA et al., 2015). Comparing mating systems in tree populations with different degrees of human disturbance is a powerful strategy to predict how these diverse variables may affect reproduction, variance effective size and number of seed trees for seed collection. Since we expect higher relatedness and inbreeding and low effective size in seeds collected from seed trees in disturbed forests (Moraes and SEbBenn, 2011; TAMbarussi et al., $2015)$, this approach is particularly valuable in designing sampling strategies aiming for ex situ conservation and breeding or even for forest restoration purposes (DEGEN and SEBBENN, 2014).

Generally, tree species populations display mixed mating systems (mixture of selfing and outcrossing) or are predominantly outcrossed (WARD et al., 2005; DEGEN and SEBbenN, 2014). Rates of outcrossing, mating among relatives, and correlated matings may vary among populations, progenies, fruits within individuals, as well as among reproductive events (SURLES et al., 1990; Silva et al., 2011; Feres et al., 2012). Thus, open-pollinated progeny may represent a mixture of self-sibs, half-sibs, full-sibs and selfhalf-sibs (FERES et al., 2012; DEGEN and SEBBENN, 2014).

Bertholletia excelsa Bonpl. (Lecythidaceae) or the Brazil nut tree is one of the most important non-timber forest tree species of Amazonian forests and is considered a model species for forest conservation. Its nuts are almost exclusively harvested from mature forests and this NTFP (non-timber forest product) has enjoyed widespread and longstanding economic success in the international market (WADT et al., 2008). This species occurs in non-flooded (terra firme) forests throughout the Amazon basin, preferentially on clay-sandy soils (PRANCE and MoRI, 1979). In some regions in Eastern Amazonia, adults are concentrated in groves (PERES and BAIDER, 1997), but in Southwestern Amazonian individuals are randomly distributed (WADT et al., 2005). It is a hermaphrodite species and may be self-incompatible, thus avoiding self-fertilization (O'MALLEY et al., 1988). Pollination is accomplished by large-bodied bees of Bombus, Centris, Xylocopa and Epicharis genera and some species of Euglossini (MAUÉs, 2002). Few genetic studies have been conducted to date, and most addressed genetic diversity and structure in natural populations (BUCKLEY et al., 1988; SuJII et al., 2015). A mating system study based on allozymes showed $B$. excelsa is predominantly outcrossing (O'MALLEY et al., 1988).

Bertholletia excelsa logging is prohibited by law in Brazil, Peru and Bolivia, where this 
species is very common and many local communities rely on $B$. excelsa seed harvest for their incomes (GUARIGUATA et al., 2009). Although it is common to find $B$. excelsa in pastureland or sometimes even in plantations, the value of these scattered trees for seed collection or in situ conservation is debated. Studies on tropical trees has been found that isolated trees in pastures are not reproductively isolated, but such trees in general present greater selfing and correlated mating than trees occurring in continuous and forest fragments (DICK et al., 2003; FuCHS et al., 2003; LANDER et al., 2010; MORAES and Sebbenn, 2011; Manoel et al., 2012). Selfing and correlated mating increase the relatedness and decrease the effective size within open-pollinated progenies and selfing increase the inbreeding within families and consequently the number of seed trees for seed collection is higher in isolated trees than in continuous or fragmented forest (MoRAEs and SEBBEnN, 2011; MANOEL et al., 2012). Isolated trees in pastures are more intensively exposed to wind and lightning storms than trees in forested areas, experiencing higher mortality rates. It is anecdotally known that seed production is heavily affected, as $B$. excelsa trees within forested matrix exhibit higher levels of seed production than their pasture-plantation counterparts. Some possible explanations of the reduced seed set are the dependence on forest-dwelling bees to accomplish pollination and reduce inbreeding depression, but no empirical study to date has evaluated how $B$. excelsa reproduction can be affected in these disturbed areas. Furthermore, there is not study about the mating system of $B$. excelsa plantation. Plantation maybe an alternative for seed collection if mating are random and open-pollinated seeds present low inbreeding, due the facility to collect seeds. This study aims to fill this gap by comparing the mating system between a group of remnant trees dispersed in pasture and trees from a plantation with natural population within forested matrice. We also explore outcrossing rate variation among and within fruits in the natural populations to more deeply characterize the mating system of this important Amazon tree species. In sum, our investigation uses microsatellite markers to compare mating system in populations with different life histories: natural mature forest, a plantation, and sparse trees in pasture. We specifically tested the following hypotheses: The human activities as spatial isolation of trees in pasture and forest plantation disturb the mating system of $B$. excelsa due changes in the behavior of the pollinator vector caused by changes in reproductive population density. Thus, we tested if the selfing rate and the paternity correlation are higher in sparse trees in pasture than trees occurring in natural forest and plantations; (2) mating among relatives is lower in sparse trees in pasture than in natural population due to intrapopulation spatial genetic structure, and than in plantations due to relatedness among individuals originated from same seed trees; (3) the paternity correlation is lower among than within fruits and; (4) the levels of variance effective size are lower and inbreeding is higher in open-pollinated seeds collected in sparse trees than seed trees occurring in plantation and natural forest.

\section{Materials and methods}

\section{Study sites}

The study was carried out in B. excelsa populations in one mature natural forest, one-plantation, and one pastureland with remnant trees. The study sites are distributed in the southern and southwestern portion of the Amazon in the Brazilian states of Acre and Mato Grosso. In Acre, one plantation and one pastureland with sparse $B$. excelsa seed trees were sampled. To statistic analysis, we defined the plantation and isolated trees in pasture as „populations“. The plantation (ACPLA) was established in 1982 in the Experimental Campus of Embrapa Acre, in Rio Branco municipality, using a spacing of $10 \mathrm{x}$ $10 \mathrm{~m}$ among trees and occupying an area of approximately 0.2 ha (100 trees/ha). Details of the provenance and number of seed trees when seeds were collected are unknown. The plantation was not isolated as there was a natural forest in the vicinity. The sparse $B$. excelsa trees (ACPAS) remnants of a native forest of 163 ha pastureland (0.31 trees/ha) within the Santa Maria farm, BR-317, km 17, Senador Guiomard municipality. This pasture lies between two other farms and there is a forest nearby. Pasture conversion took place 15 years ago. In Mato Grosso, the study was carried out in 20 ha plot (7.5 trees/ha) installed in a natural mature forest (MTFOR) in Dal Pai farm, Itaúba municipality.

\section{Sampling}

We sampled open-pollinated seeds from 14 seed trees in MTFOR, 8 seed trees in ACPAS 
and 9 in ACPLA. In ACPAS and ACPLA we sampled ten fruits per tree, obtaining an average of 30 seeds per tree. We germinated seeds in sandboxes at Embrapa Acre nursery, which were kept moist for four months. After this period, we removed seeds from the sand, peeled and placed again in the sandboxes for germination. In MTFOR, we sampled 7 fruits from each seed tree. Seeds were peeled and put to germinate in sandboxes in a greenhouse with 50\% shading. For genetic analysis, we sampled leaves from a minimum of 10 seedlings per progeny. For hierarquical analysis of mating system among and within fruits, in the MTFOR population, we kept the identity of fruits for each seedling. Leaf or trunk cambium tissues of seed trees were also collected. Leaves were dried. Tissue samples were stored at $-20^{\circ} \mathrm{C}$ until DNA purification.

\section{Microsatellite analysis}

Total genomic DNA extraction was performed using a CTAB protocol described in DOYLE and DOYLE (1990), employing an automatic tissue disruptor. DNA was quantified after electrophoresis on $1 \%$ agarose gel by comparison to known phago lambda DNA standards concentrations. DNA samples from seed trees and their progenies were genotyped with seven or eight microsatellite markers (Table 1). PCR (Polymerase Chain Reaction) amplification was performed separately for each locus, using $3 \mathrm{ng}$ or $5 \mathrm{ng}$ of DNA; 1x Taq polymerase buffer (10x, $10 \mathrm{mM}$ Tris- $\mathrm{HCl}, \mathrm{pH} 8.3,50 \mathrm{mM} \mathrm{KCl}) ; 0.25 \mathrm{mM}$ dNTPs; $0.25 \mathrm{mg} / \mathrm{ml}$ BSA; $1 \mathrm{U}$ of Taq DNA polymerase, $0.23 \mathrm{mM}$ of each primer and ultra-pure water, in a final volume of $13 \mu \mathrm{l}$. Mato Grosso and Acre studies were done independently in different laboratories so we used markers and different PCR cycling protocol (Table 1). To Acre, the analyzes were performed at Embrapa Acre's Molecular Biology Laboratory (Labmol) and to Mato Grosso, in the Embrapa Genetic Resources and Biotechnology's (Cenargen) Genetics Laboratory. In Labmol amplifications were performed in a MJ Thermocycler 96+ Biocycler according to the conditions described in DoN et al. (1991). PCR fragments were separated through capillary electrophoresis (Fragment Analyzer, FS 96, Advanced Analytical). Genotypes were determined using ProSize 2.0 software (Advanced Analytical). In Cenargen's Genetics Lab, the forward primers were labeled with fluorescent dyes and the PCR was performed on Veriti thermocycler (Applied Biosystems). A multiplexing step with two loci was assembled to perform genotyping. For each

Table 1. - Microsatellite markers (SSR) used to genotyped Bertholletia excelsa.

\begin{tabular}{|c|c|c|c|}
\hline Population & SSR & PCR program & Reterence \\
\hline $\begin{array}{l}\text { ACPLA } \\
\text { and } \\
\text { ACPAS }\end{array}$ & $\begin{array}{l}\text { Bex02, Bex03, } \\
\text { Bes 13, Bes14, } \\
\text { Bes 18, Bes 19, } \\
\text { Bex } 27 \text {, and Bex37 }\end{array}$ & 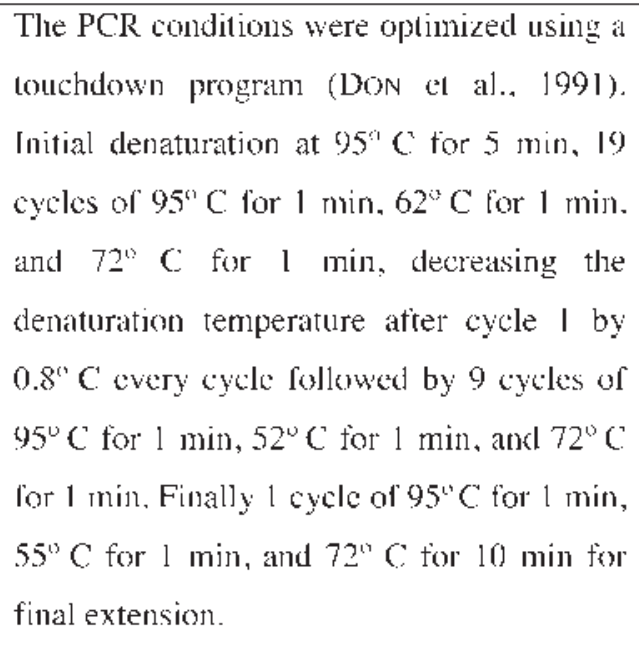 & RLiS el al.. 2009 \\
\hline MTFOR & $\begin{array}{l}\text { Bex02, Bex06, } \\
\text { Bet09, Bet12, } \\
\text { Betl 4, Bet I5, } \\
\text { and Bet } 16\end{array}$ & $\begin{array}{l}\text { Initial denaturation at } 94^{\circ} \mathrm{C} \text { for } 5 \text { mim: } 35 \\
\text { cycles of: denaturation at } 94^{\circ} \mathrm{C} \text { for I min, } \\
\text { anmealing of primers at } 56^{\circ} \mathrm{C} \text { for } 1 \mathrm{mim} \text {, } \\
\text { axtension at } 72^{\circ} \mathrm{C} \text { for } 1 \text { min and } 30 \mathrm{sec} \text { and } \\
\text { a final extension at } 72^{\circ} \mathrm{C} \text { for } 7 \text { min. }\end{array}$ & $\begin{array}{l}\text { REIs al al. 2009; } \\
\text { Stitl ct al.. } 2013\end{array}$ \\
\hline
\end{tabular}


multiplex, $1 \mu \mathrm{l}$ of each reaction was added to $9 \mu \mathrm{l}$ of Hidi and $1 \mu \mathrm{l}$ of ROX internal marker. This mixture was denatured for $5 \mathrm{~min}$ at $95^{\circ} \mathrm{C}$ and taken to an automatic analyzer ABI 3730 (Applied Biosystems). The data were interpreted using GeneMapper software. The allelic size rounding was conducted by AlleloBin software (PRASANTH et al., 2006). The amplified products were diluted and separated through electrophoresis in 5\% polyacrylamide gels in an automatic DNA sequencer ABI Prism 377 XL, following the manufacturer's instructions (Applied Biosystems Inc.). Molecular weight standards ROX and TAMRA (Applied Biosystems Inc.) were used to estimate the size of alleles. Genetic data were collected and analyzed using Genescan and Genotyper programs (Applied Biosystems Inc.).

\section{Analysis of mating system}

The mating system at population and individual seed tree levels were analyzed according to the mixed mating and correlated mating models, using the MLTR 3.1 program (RITLAND, 2002). Estimates were based on the Expectation maximization numerical method (EM). The estimated indexes were: gene frequencies of pollen and ovules, fixation index of seed trees $\left(F_{m}\right)$, multilocus $\left(t_{m}\right)$ and single-locus outcrossing rates $\left(t_{s}\right)$, mating among relatives $\left(t_{m}-t_{s}\right)$, self- ing correlation $\left(r_{s}\right)$ and paternity correlation $\left(r_{p}\right)$. In MTFOR, the multilocus paternity correlation was also estimated within $\left(r_{p(w)}\right)$ and among $\left(r_{p(a)}\right)$ fruits. The $95 \%$ confidence intervals $(95 \% \mathrm{CI})$ of the estimated indexes were calculated based on 1,000 bootstraps among individuals within progeny as re-sampling unity.

The mating system parameters were used to estimate the effective number of pollen donors among and within fruits $\left(N_{e p}=1 / r_{p}\right)$, within fruits $\left(N_{e p(w)}=1 / r_{p(w)}\right)$ and, among fruits $\left(N_{e p(a)}=1 / r_{p(a)}\right)$, following RITLAND (1989), mean coancestry coefficient within progeny $(\Theta=0.125$ $\left(1+F_{m}\right)\left[4 s+\left(t^{2}{ }_{m}+t_{m} s r_{s}\right)\left(1+r_{p}\right)\right]$, where $s$ is the selfing rate $\left(s=1-t_{m}\right)$ following SEBBENN (2006). The variance effective size within progeny was estimated from the variance of gene frequencies due to genetic drift $\left(\sigma^{2} p\right)$, as derived by CockerHAM (1969): $\left.\quad \sigma^{2} p=[(n-1) / n) \Theta+\left(1+F_{o}\right) / 2 n\right]$ $p(1-p)$, where $n$ is the sample size within progeny, $p$ is frequency for a given neutral allele, and $F_{O}$ is the average inbreeding coefficient. As in an idealized population (without relatedness among individuals and inbreeding) under random mating, the corresponding $\sigma^{2} p$ value for a group of $n$ offspring is $\sigma^{2} p=p(1-p) /(2 n)$, in which we can assume for an arbitrary reference population this variance as $\sigma^{2} p=p(1-p) /\left(2 N_{e}\right)$. Thus, we can equate both $\sigma_{p}^{2}$ expressions to

Table 2. - Average inbreeding and mating system estimates in Bertholletia excelsa populations with 95\% confidence intervals in parentheses $(95 \% \mathrm{CI})$. Values with dissimilar letters in the same line are significantly different, according to the $95 \%$ confidence interval.

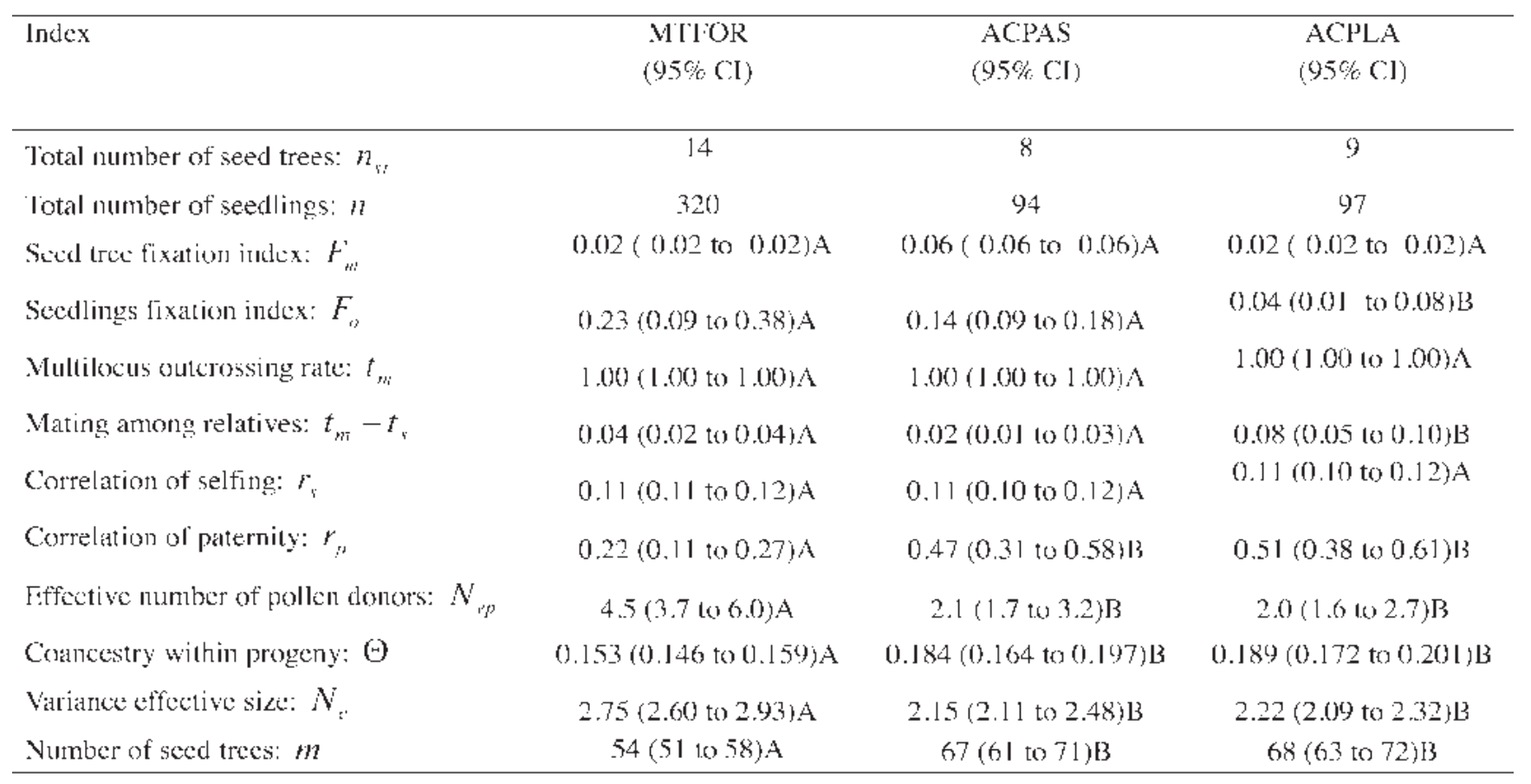


derive the variance effective size within progeny as,

$$
N_{e}=\frac{0.5}{\Theta\left(\frac{n-1}{n}\right)+\frac{1+F_{o}}{2 n}} .
$$

This expression was used for computing $N_{e}$ for population and progeny arrays. To determine whether there was inbreeding in seedlings, we used the within population fixation index, $F_{o}=1-\left(H_{o} / H_{e}\right)$, where $H_{o}$ and $H_{e}$ are observed and expected heterozygosities, respectively (NEI, 1977). However, due to the fact that plants within progeny inherited at least one of the maternal alleles, which may result in an overestimation of gene frequencies of maternal alleles, $F_{o}$ for mean population and progeny array was estimated using the $H_{o}$ estimated for each population and mean progeny array, and $H_{e}$ esti- mated from gene frequencies of pollen pool of each population. The $H_{o}$ was estimated using FSTAT program (GoUDET, 1995) and $H_{e}$ by $H_{e}=1-\Sigma p^{2}$, where $p$ is the frequency of each allele of a given locus in pollen pool (NEI, 1977). In $\Theta$ and $N_{e}$ calculation, negative $F_{m}$ and $F_{a}$ estimates were assumed to be zero, because these indexes were derived from the inbreeding coefficient (which ranges from 0 to 1 ) and not from the fixation index (which ranges from -1 to 1). The minimum number of seed trees required for harvesting seeds for conservation purposes was estimated by $m=N_{e(r)} / N_{e}$, where $N_{e(r)}$ is the required effective population size (SEBBENN, 2006). We assumed a $N_{e(r)}$ of 150 (LACERDA et al., 2008). The 95\% CI of these indexes was estimated using lower $(l)$ and upper $(u)$ values of the parameters estimated by bootstraps:

Table 3. - Inbreeding and mating system indices at the individual level in three Bertholletia excelsa populations (MTFOR, ACPAS, and ACPLA).

\begin{tabular}{|c|c|c|c|c|c|c|c|c|c|}
\hline Sect-lyee & fl & $F_{n: 1}^{\prime}$ & $F_{i}$ & $t_{m} \pm S \mathcal{D}$ & $t_{m}-t_{n} \pm \mathrm{G} \mathrm{D}$ & $r_{r} \pm S \mathrm{D}$ & $N_{i p}$ & $\Theta$ & $N$ \\
\hline MTГOR-I & 19 & -0.47 & 0.14 & $0.99-0.01$ & $0.07-0.01$ & $0.07+0.02$ & 14.3 & 0.136 & 3.15 \\
\hline MTlOR-2 & 13 & -0.12 & 0.13 & $0.96-0.04$ & $005=0.03$ & $0.18 \perp 0.06$ & 5.6 & 0.150 & 2.67 \\
\hline MTFOR-3 & 14 & -0.33 & 0.30 & $0.99=0.00$ & $005=001$ & $0.20 \pm 0.07$ & 50 & 0.152 & 2.67 \\
\hline $\mathrm{M}+\mathrm{HOR}-4$ & 11 & -0.20 & 0.38 & $0.94 \cdot 0.05$ & $0.06 \cdot 0.04$ & 0.1810 .03 & 5.6 & 0.160 & 2.40 \\
\hline MTFOR-5 & 22 & -0.08 & 0.45 & $0.95=0.05$ & $0.08=0.04$ & $0.29 \pm 0.10$ & 3.4 & 0.171 & 2.55 \\
\hline MIFOR- 6 & 15 & -0.12 & 0.28 & $0.99-0.00$ & $0,06-0.0$ & $0.21+0.07$ & 4.8 & 0.153 & 2.69 \\
\hline MITFOR-7 & 19 & -0.012 & 0.53 & $0.90 \cdot 0.07$ & $0.02 \cdot 0.06$ & $0.08 \perp 0.02$ & 12.5 & 0.159 & 2.61 \\
\hline MTFOR-8 & 16 & -0.68 & -0.02 & $0.99-0.00$ & $0.05-0.00$ & $0.20+0.05$ & 50 & 0.152 & 2.88 \\
\hline MTFOR-9 & 19 & -1031 & 0.24 & $0.96 \cdot 0.04$ & $0.07 \cdot 0.03$ & 0.1310 .06 & 7.7 & 0.150 & 2.86 \\
\hline MTFOR-I0 & 45 & 0.16 & 0.30 & $0.98-0.03$ & $0,05-0.02$ & $0.07+0.03$ & 14.3 & 0.161 & 2.92 \\
\hline MTIOR-II & 51 & -0.75 & 0.16 & $1.00 \cdot 0.90$ & $0.02-0.00$ & $0.10 \perp 0.04$ & 10.0 & 0.138 & 3.42 \\
\hline MTFOR-12 & 22 & -0.73 & 0.07 & $1.00=0.00$ & $0.06=0.01$ & $0.08 \pm 0.02$ & 12.5 & 0.135 & 3.26 \\
\hline MTlOOR I3 & 26 & 0.88 & 0.20 & $0.95=0.08$ & $0.02=0.077$ & $0.05 \pm 0.01$ & 20.0 & 0.143 & 3.11 \\
\hline MTHOR-14 & 28 & -0.51 & 0.12 & $1.00-0.000$ & $006-0.01$ & $0.29+10.06$ & 3.4 & 0.161 & 2.85 \\
\hline ACPAS 7 & 12 & [1.] I & 0.20 & $1.00=0.00$ & $0.01=0.01$ & $0.39 \pm 0.15$ & 2.6 & 0.174 & 2.79 \\
\hline ACPAS-II & 12 & 0.11 & 0.09 & $1.60-0.000$ & $0.12-0.04$ & $0.51+0.17$ & 2.0 & 0.210 & 2.11 \\
\hline$A C P^{x} A 12$ & 11 & 0.11 & 0.04 & $1.00=0.00$ & $0.01=0.01$ & $0.39 \pm 0.16$ & 2.6 & 0.174 & 2.44 \\
\hline ACPAS-I & 12 & 0.01 & 0.10 & $1.600-10.000$ & $0.02-0.000$ & $0.1]+0.16$ & 9.1 & 0.140 & 2.87 \\
\hline ACPAS 5 & 12 & 0.21 & 0.20 & $1.00=0.00$ & $0.11=0.04$ & $0.35 \pm 0.16$ & 2.9 & 0.160 & 2.44 \\
\hline АСРАS-3 & 12 & -0.40 & 0.18 & $0.98-11.06$ & $0.07-0.05$ & $0.3]+0.17$ & 3.2 & 0.167 & 2.47 \\
\hline$A C H^{P} A S-18$ & 11 & -0.24 & 0.09 & $1,00=0,00$ & $0.09=0.04$ & $0,06 \pm 0,04$ & 16.7 & 0.1 .33 & 2.94 \\
\hline$\triangle C P A S-20$ & 12 & -0.00 & 0.21 & $100=000$ & $0.08=0.01$ & $0.70 \pm 0.18$ & 1.4 & 0.213 & 2.04 \\
\hline$A C P^{P} L A-30$ & 12 & -0.40 & -0.15 & $1.00-0.00$ & $002 \pm 001$ & $0.08 \pm 6.97$ & 120 & 0.135 & 3.62 \\
\hline ACPIA-45 & 11 & 0.16 & 0.18 & $1.00 \cdot 0.00$ & $0.11 \pm 0.033$ & $0.92 \pm 0.17$ & 1.1 & 0.278 & 1.63 \\
\hline ACPLA-34 & 8 & 0.31 & 0.08 & $1,00-0.00$ & $0.06 \pm 0.02$ & $0.81 \pm 0.26$ & ]. 2 & 0.297 & 1.52 \\
\hline АCPI.A-76 & 12 & -10.33 & 0.01 & $1.00 \cdot 0.00$ & $0.07 \pm 0.02$ & $0.67 \pm 0.20$ & 1.5 & 0.209 & 2.14 \\
\hline ACPLA-47 & 11 & -0.23 & -0.06 & $1.00-0.00$ & $0.04 \pm 0.01$ & $0.55 \pm 0.26$ & 1.8 & 0.194 & 2.26 \\
\hline ACPI A-50 & 12 & -0.12 & 0.16 & $1.00 \cdot 0.00$ & $0.13 \pm 0.04$ & $0.10 \pm 0.34$ & 10.3 & 0.137 & 2.88 \\
\hline ACPLA-71 & 8 & 0.19 & 0.05 & $1.00-0.00$ & $0.15 \pm 0.015$ & $0.23 \pm 0.75$ & 4.3 & 0.184 & 2.21 \\
\hline ACPI.A-5] & 11 & -0.10 & 0.12 & $1,00 \cdot 0.00$ & $0.17 \pm 0.013$ & $0.31 \pm 0.27$ & 3.2 & 0.164 & 2.51 \\
\hline$\triangle C P^{2} A-54$ & 12 & 0.74 & 0.02 & $1.000-0.000$ & $0.34 \pm 0.05$ & $0.98 \pm 0.11$ & 10 & 0.4 .31 & 1.14 \\
\hline
\end{tabular}

$n$ is the sample size; $F_{m}$ and $F_{o}$ are the fixation index of seed trees and seedlings, respectively; $t_{m}$ is the multilocus outcrossing rate; $t_{m}-t_{s}$ is the mating among relatives rate; $r_{p}$ is the multilocus correlation of paternity; $N_{e p}$ is the effective number of pollen donors; $\Theta$ is the coancestry coefficient within progeny; $N_{e}$ is the variance effective size; SD is the standard deviation. 
$N_{e p(l)}=1 / r_{p(u)}, N_{e p(u)}=1 / r_{p(l)}, N_{e p(a)(l)}=1 / r_{p(a)(u)}$,

$N_{e p(a)(u)}=1 / r_{p(a)(u)}, N_{e p(w)(l)}=1 / r_{p(w)(u)}$,

$N_{e p(w)(u)}=1 / r_{p(w)(l)}, P_{s s(l)}=\left(1-t_{m(u)}\right)^{2}$,

$P_{s s(u)}=\left(1-t_{m(l)}\right)^{2}, P_{h s(l)}=t^{2}{ }_{m(l)}\left(1-r_{p(u)}\right)$,

$P_{h(u)}=t^{2}{ }_{m(u)}\left(1-r_{p(l)}\right), P_{f_{s}(l)}=t^{2}{ }_{m(u)}\left(1-r_{p(l)}\right)$,

$P_{f_{s}(u)}=t^{2}{ }_{m(u)} r_{p(u)}, P_{s h s(l)}=2 t_{m(u)}\left(1-t_{m(u)}\right)$,

$P_{s h s(u)}=2 t_{m(l)}\left(1-t_{m(l)}\right)$,

$\Theta_{(l)}=0.125\left(1+F_{m(l)}\right)\left[4 s_{(l)}+\left(t_{m(u)}^{2}+\right.\right.$

$\left.\left.t_{m(u)} s_{(l)} r_{s(l)}\right)\left(1+r_{p(l)}\right)\right]$,

$\Theta_{(u)}=0.125\left(1+F_{m(u)}\right)\left[4 s_{(u)}+\left(t^{2}{ }_{m(l)}+\right.\right.$

$\left.\left.t_{m(l)} s_{(u)} r_{s(u)}\right)\left(1+r_{p(u)}\right)\right]$,

$\left.N_{e(l)}=0.5 /\left\{\Theta_{(u)}[n-1) / n\right]+\left(1+F_{o(u)}\right) / 2 n\right\}$,

$\left.N_{e p(u)}=0.5 /\left\{\Theta_{(l)}[n-1) / n\right]+\left(1+F_{o(l)}\right) / 2 n\right\}$,

$m_{(l)}=N_{e(r)} / N_{e(u)}$ and $m_{(u)}=N_{e(r)} / N_{e(l)}$.

\section{Results}

\section{Inbreeding}

In all populations the mean fixation index of seed trees $\left(F_{m}\right)$ was significantly negative
(Table 2). At the seed tree level, $F_{m}$ was smaller than zero in most of the seed trees, although some presented values higher than zero, indicating in this case inbreeding and variation among trees (Table 3). On the contrary, the fixation index of seedlings $\left(F_{o}\right)$ was significant higher than zero in all populations, ranging from 0.04 to 0.23 (Table 2). The fixation index within progeny $\left(F_{o}\right)$ was higher than zero in all the ACPAS progenies and in $93 \%$ of MTFOR progenies. In ACPLA we observed a slightly larger variation in $F_{o}$ among trees, as $78 \%$ of the progenies had greater than zero. Comparing $F_{m}$ and $F_{o}$, the $F_{m}$ was significantly lower than $F_{o}$ in all populations, suggesting selection for heterozygous individuals from seedling to adult stages.

\section{Mating system}

The population outcrossing rate $\left(t_{m}\right)$ was not significantly lower than unity (1) in the populations (Table 2). The mating among relatives rate $\left(t_{m}-t_{s}\right)$ was significantly greater than zero in all populations (Table 2), but was signifi-

Table 4. - Paternity correlation and effective number of pollen donors among and within fruits in MTFOR population.

\begin{tabular}{|c|c|c|c|c|}
\hline Progeny & $r_{p=1: 1}=\mathrm{SD}$ & $r_{p, a \mathrm{ai}}=\mathrm{SD}$ & $N_{(, m i n j)}$ & $N_{(x+1)(1)}$ \\
\hline 1 & $0.08+0.49$ & $0.07-0.02$ & 13.2 & 13.9 \\
\hline 2 & $0.8] 10.23$ & $0.08 \cdot 0.00$ & 1.2 & 13.0 \\
\hline 3 & $0.52 \perp 0.35$ & $0.17-0.06$ & 1.9 & 5.8 \\
\hline 4 & $1.00 \perp 0.01$ & $0.10 \_0.01$ & 1.0 & 9.6 \\
\hline 5 & $0.40+0.25$ & $0.25-0.08$ & 2.5 & 4.0 \\
\hline 6 & $0.94 \pm 0.22$ & $0.15=0.05$ & 1.1 & 6.6 \\
\hline 7 & $0.44+0.40$ & $0.07-0.02$ & 2.2 & 14.3 \\
\hline 8 & $0.35 \pm 0.24$ & $0.18=0.04$ & 2.9 & 5.4 \\
\hline 9 & $0.3] \perp 0.38$ & $0.11=0.04$ & 3.2 & 8.8 \\
\hline 10 & $0.35 \pm 0.14$ & $0.04=0.02$ & 2.8 & 24.4 \\
\hline 11 & $0.16 \pm 0.10$ & $0.08=0.04$ & 6.2 & 12.2 \\
\hline 12 & $0.08 \pm 0.44$ & $0.08=0.02$ & 13,3 & 12.3 \\
\hline 13 & $0.13 \pm 0.37$ & $0.05=0.01$ & 7.8 & 22.2 \\
\hline 14 & $0.23 \pm 0.25$ & $0.29=0.06$ & 4.4 & 3.5 \\
\hline Mean $(95 \%$ CI) & $0.41(0.26-0.58)$ & $0.18(0.05-0.31)$ & $2.4(1.7-3.8)$ & $5.6(3.2-200)$ \\
\hline
\end{tabular}

$r_{p(w)}$ and $r_{p(a)}$ are the paternity correlation within and among fruits, respectively; $N_{e p(w)}$ and $N_{e p(a)}$ are the effective number of pollen donors within and among fruits, respectively; SD is the standard deviation; $95 \% \mathrm{CI}$ is the $95 \%$ confidence interval. 
cantly higher in ACPLA (0.08) than ACPAS and ACPLA. At the level of seed trees, $t_{m}-t_{s}$ was significant higher than zero in 12 progeny from MTFOR (86\%), six from ACPAS (75\%) and all from ACPLA (100\%), suggesting biparental inbreeding within progeny arrays (Table 3 ). The selfing correlation $\left(r_{s}\right)$ was low and not significantly different among populations, suggesting low variation in individual outcrossing rate (Table 2). The paternity correlation within and among fruits $\left(r_{p}\right)$ was significantly higher than zero in all the populations, revealing that progeny arrays have some full-sibs seedlings (Table 2). MTFOR natural population present significant lower $r_{p}$ and higher effective number of pollen donors $\left(N_{e p}\right)$ than ACPLA and ACPAS human altered populations. The $r_{p}$ and $N_{e p}$ were also quite variable among progenies in all the three populations (Table 3). The mean coancestry coefficient within progeny $(\Theta)$ was significantly lower and variance effective size significant higher in MTFOR than in ACPAS and ACPLA (Table 2). The coancestry within progeny $(\Theta)$ and variance effective size $\left(N_{e}\right)$ were also quite variable in all the populations. The number of seed trees required for seed collection $(m)$ to ensure that an effective population size of 150 would be retained in progeny arrays was slightly lower in MTFOR (54) than ACPAS (67) and ACPLA (68).

\section{Correlated mating among and within fruits}

The hierarchical paternity correlation in MTFOR (Table 4) was significant higher within $\left(r_{p(w)}=0.41\right)$ than among fruits $\left(r_{p(a)}=0.18\right)$. Consequently, the effective number of pollen donors was lower within fruits $\left(N_{e p(w)}=2.4\right)$ than among fruits $\left(N_{e p(a)}=5.6\right)$. At the level of seed trees, $r_{p(w)}$ and $r_{p(a)}$ were very variable among progenies $\left(r_{p(w)}\right.$ ranged from 0.07 to 1.00; $r_{p(a)}$ ranged from 0.04 to 0.29$), r_{p(w)}$ and was significantly higher than zero in nine progenies as was $r_{p(a)}$ in all the 14 progenies. $N_{e p(w)}$ ranged among progeny from 1.0 to 13.3 among progenies and $N_{e p(a)}$ ranged from 3.5 to 24.4.

\section{Discussion}

Our results clearly showed human activity as spatial isolations of trees in pasture and plantation affect mating patterns in $B$. excelsa populations, as highest mating among relatives rate in plantation due greatest relatedness between reproductive trees and higher correlated matings and lower effective number of pollen donors fertilizing isolated trees and trees in plantation due the changes in population density of reproductive trees affecting the pollinators' foraging behaviour and altering pollen dispersal patterns. Consequently, the coancestry coefficient and effective size within family were also affected. We observed also individual variation in mating among relatives and correlated mating, as well as correlated mating variation within and among fruits. These results have strong implications for selection of seeds for conservation, breeding, and reforestation purposes.

\section{Outcrossing rate and correlated mating}

Our studied $B$. excelsa populations produced seeds predominantly by outcrossing, corroborating previous findings (O'MALLEY et al., 1988). We observed small variation in $t_{m}$ among trees within populations (ranging from 0.94 to 1.0), suggesting that some degree of selfing may occur. However, the significant lower than 1.0 outcrossing rate probably occurred due the low number of seeds analyzed in same progenies. The lowest individual outcrossing rate (0.94) was observed in a progeny with only 11 seedlings. Furthermore, in a hand pollination experiment, CAVALCANTE et al. (2012) showed that self-pollinated flowers set no fruits. Thus, the species probably only produce seeds from outcrossing due self-incompatibility or inbreeding depression.

We hypothesized that selfing and paternity correlations would be higher in seed trees from pasture due to the absence of a forested matrix. The distance between remnant trees in a pasture may hamper the flying of pollinating bees from tree to tree, increasing geitonogamy and selfing and decreasing the number of pollen donors. Such increased selfing in pasture trees has been detected in other tropical trees (FUCHS et al., 2003; Moraes and SebBenn, 2011; Breed et al., 2012). However, we observed no selfing in pasture trees, which indicates that a mechanism of self-incompatibility prevents inbreeding in B. excelsa, as was detected in a hand pollination experiment (CAVALCANTE et al., 2012). Additionally, because fruit set is heavily compromised in pasture trees, we believe that both the small assemblage of pollinating bees in this disturbed environment and their compro- 
mised forage behavior (visiting more flowers on the same tree) contribute to few fertilized flowers and high fruit abortion. In $B$. excelsa, fruit abortion may be a consequence of both post fertilization self-incompatibility and inbreeding depression. In fact, seeds from two of the sampled ACPAS seed trees did not germinate, perhaps due to inbreeding depression. As we genotyped seedlings, seeds that failed to germinate were not accounted for in our inbreeding estimates. The genetic load may be variable among $B$. excelsa populations Variation in germination, survival and growth traits has been observed in field trials of tree species (KÄRKKÄINEN et al., 1996; HARDNER and Potts, 1997; KoELEWIJN et al., 1999), showing that levels of genetic load vary among seed trees and populations. Furthermore, HUFFORD and HAMRICK (2003) clearly showed an increase in outcrossing rate between fertilization $\left(t_{m}=0.79\right)$ and seedling stages $\left(t_{m}=0.91\right)$ in the tropical tree Platipodiun elegans. Thus, our results suggest that population and individual variation in genetic load may be the cause of variation in outcrossing rates.

In contrast, our results did support the hypothesis of increased correlated matings in pasture and planting trees than in natural forest, as the number of pollen donors in pasture progenies was smaller than MTFOR. Differences in average distance among flowering trees may explain this variation amongst forest populations. While in MTFOR the average distance between trees was $16 \mathrm{~m}$, in ACPAS it was $60 \mathrm{~m}$. The long distance flight capacity of pollinating bees did not compensate for the advantageous higher density of flowering trees and thus larger neighboring pollinator area and number of pollen donors observed in the forest matrix (SANTOS and AISY, 2012). On the contrary, the number of pollen donors in the plantation was similar to ACPAS, even though the distance among trees in ACPLA was only $10 \mathrm{~m}$. This apparently incoherent result is explained by the relatedness of trees in the plantation; seeds were probably collected from a small number of trees, which reduces the effective number of pollen donors and possibly the percentage of trees that flower every year. Higher estimates of correlated matings in isolated seed trees in pastures than in forest fragments or continuous forest has also been observed in Paquira quinata (Fuchs et al., 2003) and Swietenia macrophylla (BREED et al., 2012).

\section{Correlated mating among and within fruits}

Our results of the hierarchical paternity correlation showed that correlated matings were higher within fruits $\left(r_{p(w)}=0.41\right)$ than among fruits $\left(r_{p(a)}=0.18\right)$, indicating that on average, three pollen donors effectively fathered each fruit, but each seed tree progeny had six fathers. Thus, the probability of finding full-sibs is higher within fruits than among fruits of a given seed tree. This result is important to guide strategic seed collection, recommending the gathering of a larger number of fruits per tree as will be present in section Recommendation for conservation and reforestation. Our results are in line with other studies of mating system in insect pollinated tree species, where higher correlated mating within than among fruits have also been reported (SAMPSON, 1998; Silva et al., 2011; Feres et al., 2012; MANOEL et al., 2015; TAMBARUSSI et al., 2015). However, the effective number of pollen donors varied from tree to tree and ranged from 1.0 to 13.3 within fruits and from 3.5 to 24.4 among fruits, indicating that some seed trees received pollen from fewer pollen donors than others, and that the probability of finding full-sibs within and among fruits was higher in some seed trees. Bertholletia excelsa is pollinated by large bees and pollen carryover from recently visited tree can be leading to many seeds within fruits having the same father and seeds from different fruits originating from different fathers (SURLES et al., 1990).

\section{Mating among relatives and inbreeding}

Mating among related trees $\left(t_{m}-t_{s}\right)$ varied among populations, reaching the highest estimate in ACPLA. In general, natural populations of tree species present a particular spatial genetic structure (SGS) due to limited seed dispersal (DEGEN and SebBenn, 2014). This leads to greater relatedness between closest trees, and may result in mating among relatives if related individuals flowering synchronous and pollinator vectors flying between near-neighbors cospecific individuals.

We also believe that in $B$. excelsa mating among relatives is the main cause of inbreeding in seedlings, as selfing is not common. Inbreeding was in higher in seedlings than in seed trees, suggesting selection for heterozygous individuals between seedlings to adult stages. This same phenomenon has been observed in 
other tree species (HUFFORD and HAMRICK, 2003; Bittencourt and SebBenN, 2007) and seems to be a pattern in sessile long-lived plants such as B. excelsa. Inbreeding depression tends to eliminate homozygous individuals carrying deleterious alleles.

\section{Recommendation for conservation and reforestation}

The variance effective size $\left(N_{e}\right)$ was higher in seeds collected from the natural population (2.75) than from pasture (2.15) and plantation (2.22). Consequently, more seed trees should be targeted for seed collection in pasture $(m=67)$ and plantation $(m=68)$ than in natural forest $(m=54)$, although these more disturbed sites will have a limited number of trees bearing fruits. The number of fruits sampled per tree is also important, as revealed by the higher correlated mating within than among fruits and highest biparental inbreeding within fruits. The number of fruits should be maximized and the number of seeds sampled per fruit should be minimized to decrease the relatedness among seeds and increase the effective size of the collected progeny array.

Despites the longstanding debate on the conservation value of remnant $B$. excelsa trees in pastures, this is the first study to date that addressed the mating system in this human altered environment. We also compared this situation with trees in a plantation and natural population. Our results support the hypothesis of partial self-incompatibility, which prevents self-fertilization but not mating among relatives. We believe that inbreeding depression is the major reason for similar rates of selfing and inbreeding observed in this human altered and the natural populations. We also hypothesized that distance between flowering trees and a forested matrix play important roles in promoting pollen flow in $B$. excelsa. To test this hypothesis, sampling pastures with varying densities of remnant trees would be necessary.

\section{Acknowledgments}

This work was supported by grants from Embrapa Acre, Embrapa Agrossilvipastoril, Embrapa Amazônia Oriental and Conselho Nacional de Desenvolvimento Científico e Tecnológico (CNPq Process $\mathrm{n}^{\circ}$ 556406/2009-5). VANESSA SANTOS Silva received a scholarship from CNPq (384898/2013-3) and AlEXANDRE Magno SEBbenn, is recipient of a research fellowship from CNPq. We thank Embrapa technicians and research interns for their superior field and laboratory assistance and KAREN KAINER for English review.

\section{References}

Aguilar, R., M. Quesada, L. Ashworth, Y. HerreRIAS-DIEGO and L. Lobo (2008): Genetic consequences of habitat fragmentation in plant populations: susceptible signals in plant traits and methodological approaches. Molecular Ecology 17: 5177-5188.

Arruda, C. C. B., M. B. Sikva, A. M. Sebbenn, M. Kanashiro, M. R. Lemes and R. Gribel (2015): Mating system and genetic diversity of progenies before and after logging: a case study of Bagassa guianensis (Moraceae), a low-density dioecious tree of the Amazonian forest. Tree Genetics \& Genomes 11: $1-9$.

Bittencourt, J. M. and A. M. Sebbenn (2007): Patterns of pollen and seed dispersal in a small fragmented population of a wind pollinated Araucaria angustifolia in southern Brazil. Heredity 99: 580591.

Breed, M. F., M. H. K. Marklund, K. M. Ottewell, M. G. Gardner, J. B. C. Harris and A. J. Lowe (2012): Pollen diversity matters: revealing the neglected effect of pollen diversity on fitness in fragmented landscapes. Molecular Ecology 21: 5955-5968.

Burcley, D. P., D. M. O’malley, V. Apsit, G. T. PRANCE and K. S. BAWA (1988): Genetics of Brazil nut (Bertholletia excelsa Humb. \& Bonpl.: Lecythidaceae). 1. Genetic variation in natural populations. Theoretical and Applied Genetics 76: 923-928.

Cavalcante, M. C., E. E. Oliveira, M. M. Maues and B. M. Freitas (2012): Pollination requirements and the foraging behavior of potential pollinators of cultivated Brazil nut (Bertholletia excelsa Bonpl.) trees in Central Amazon Rainforest. Psyche 2012: 1-9.

CockerhaM, C. C. (1969): Variance of gene frequencies. Evolution 23: 72-84.

Degen, B. and A. M. Sebbenn (2014): Genetics and tropical forests. In: PANCEL, L. and M. KÖLH, editors. Tropical Forestry Handbook, $2^{\text {nd }}$ ed. Berlin Heidelberg: Springer Verlag; p. 1-30.

Dick, C. W., G. Etchelecu and F. Asterlitz (2003): Pollen dispersal of Neotropical trees (Dinizia excelsa: Fabaceae) by native insects and Africa honeybees in pristine and fragmented Amazonian rainforest. Molecular Ecology 12: 753-764.

Don, R. H., P. T. Cox, B. J. Wainwright, K. BAKer and J. S. MATTICK (1991): 'Touchdown' PCR to circumvent spurious priming during gene amplification. Nucleic Acids Research 4008. 
Doyle, J. J. and J. L. Doyle (1990): Isolation of plant DNA from fresh tissue. Focus 12: 13-15.

Feres, J. M., A. M. Sebbenn, M. C. Guidugli, M. A., Mestriner, M. L. T. Moraes and A. L. AlzateMARIN (2012): Mating system parameters at hierarchical levels of fruits, individuals and populations in the Brazilian insect-pollinated tropical tree, Tabebuia roseo-alba (Bignoniaceae). Conservation Genetics 13: 393-405.

Finer, M. S. and M. T. MorGAN (2003): Effects of natural rates of geitonogamy on fruit set in Asclepias speciosa (Apocynaceae): evidence favouring the plant's dilemma. American Journal of Botany 90: 1746-1750.

Fuchs, E. J., J. A. Lobo and M. QuesadA (2003): Effects of forest fragmentation and flowering phonology on the reproductive success and mating patterns of the tropical dry forest tree Pachira quinata. Conservation Biology 17: 149-157.

Good-Avila, S. W., D. MAJumder, H. Amos and A. G. STEPHENSON (2008): Characterization of self-incompatibility in Campanula rapunculoides (Campanulaceae) through genetic analyses and microscopy. Botany 86: 1-13.

Goodwillie, C., S. Kalisz and C. G. Eckert (2005): The evolutionary enigma of mixed mating systems in plants: Occurrence, Theoretical explanations, and empirical evidence. Annual Review of Ecology, Evolution, and Systematics 36: 47-79.

GoudET, J. (1995): Fstat. (Version 2.9.3.2.): a computer program to calculate $F$-statistics. Journal of Heredity 86: 485-486.

Guariguata, M. R., J. C. Licona, B. Mostacedo and P. CRonkleton (2009): Damage to Brazil nut trees (Bertholletia excelsa) during selective timber harvesting in Northern Bolivia. Forest Ecology and Management 258: 788-793.

Hardner, C. M. and B. M. Potts (1997): Postdispersal selection following mixed mating in Eucalyptus regnans. Evolution 51: 103-111.

HuFford, K. M. and J. L. HAMrICK (2003): Viability selection at three early life stages of the tropical tree, Platypodium elegans (Fabaceae, Papilionoideae); Evolution 57: 518-526.

Kalisz, S., D. W. Vogler and K. M. HANley (2004): Context-dependent autonomous self-fertilization yields reproductive assurance and mixed mating. Nature 430: 884-887.

KÄRKKÄINEN, K. and O. SAVOLAINEN (1993): The degree of early inbreeding depression determines the selfing rate at the seed stage: Model and results from Pinus sylvestris (Scots pine). Heredity 71: 160-166.

KÄRKKÄINEN, K., V. KoskI and O. SAVOLAINEN (1996): Geographical variation in the inbreeding depression of scots pine. Evolution 50: 111-119.

KoelewiJn, H. P., K. KÄRKKÄInen, V. Koski and O. Savolainen (1999): Magnitude and timing of inbreeding depression in Scots Pine (Pinus sylvestris L.). Evolution 53: 758-768.

LaCERDA, E. B. L., A. M. SEbBenn and M. Kanashiro (2008): Long-pollen movement and deviation of random mating in a low-density continuous population of Hymenaea courbaril in the Brazilian Amazon. Biotropica 40: 462-470.

LANDER, T. A., D. H. Boshier and S. A. HARris (2010): Fragmented but not isolated: Contribution of single trees, small patches and long distance pollen flow to genetic connectivity for Gomortega keule, and endangered tree. Biological Conservation 143: 2383-2590.

Lowe, A. J., D. Boshier, M. WArd, C. F. E. Bacles and C. NAVARRo (2005): Genetic resource impacts of habitat loss and degradation; reconciling empirical evidence and predicted theory for Neotropical trees. Heredity 95: 255-273.

Manoel, R. O., P. Alves, C. Dourado, A. P. S. C. Gaino, M. L. M. Freitas, M. L. T. Moraes and A. M. SEBbenn (2012): Contemporary pollen flow, mating patterns and effective population size inferred from paternity analysis in a small fragmented population of the Neotropical tree Copaifera langsdorffii Desf. (Leguminosae-Caesalpinioideae). Conservation Genetics 13: 613-623.

Manoel, R. O., M. L. M. Freitas, E. Furlani Junior, P. F. Alves, M. L. T. Moraes and A. M. SebbenN (2015): Individual, fruit, and annual variation in correlated mating in a Genipa americana population. Silvae Genetica 64: 108-116.

MauÉs, M. M. (2002): Reproductive phenology and pollination of the Brazil nut tree (Bertholletia excelsa Humb. \& Bonpl. Lecythidaceae) in Eastern Amazonia. In: Kevan, P. and V. L. I. FonsecA. Pollinating bees - the conservation link between agriculture and nature. Brasilia: Ministry of the Environment, pp 245-254.

Millar, M. A., M. Byrne, D. J. Coates, M. J. C. Stukely and J. A. MCCom (2000): Mating system studies in jarrah, Eucalyptus marginata (Myrtaceae). Australian Journal of Botany 48: 475-479.

Moraes, M. L. T. and A. M. Sebbenn (2011): Pollen dispersal between isolated trees in the Brazilian savannah: A case study of the Neotropical tree Hymenaea stigonocarpa. Biotropica 43: 192-199.

NEI, M. (1977): $F$-statistics and analysis of gene diversity in subdivided populations. Annals Human Genetics 41: 225-233.

O'Malley, D. M., D. P. Buckley, G. T. Prance and K. S. BAWA (1988): Genetics of Brazil nut (Bertholletia excelsa Humb. \& Bonpl.: Lecythidaceae). Theoretical and Applied Genetics 76: 929-932.

Peres, C. A. and C. BAIDER (1997): Seed dispersal, spatial distribution and population structure of Brazil nut trees (Bertholletia excelsa) in Southeastern Amazonia. Journal of Tropical Ecology 13: 595-616.

Prance, G. T. and A. S. Mori (1979): Lecythidaceae Part I: The actinomorphic flowered New World Lecythidaceae. Flora Neotropica 21: 1-270.

Prasanth, V. P., S. Chandra, D. A. Hoisington and B. JAYASHREE (2006): AlleloBin-a program for allele binning of microsatellite markers based on the algorithm of Idury and Cardon, 1997. Delhi (India): ICRISAT. International Crops Research Institute for the Semi-Arid Tropics. 
Reis, A., A. Braga, M. Lemes, R. Gribel and R. CollEVATTI (2009): Development and characterization of microsatellite markers for the Brazil nut tree Bertholletia excelsa Humb. \& Bonpl.(Lecythidaceae). Molecular Ecology Resources 9: 920-923.

RITLAND, K. (1989): Correlated matings in the partial selfer Mimulus guttatus. Evolution 43: 848-859.

RITLAND, K. (2002): Extensions of models for the estimation of mating systems using $\mathrm{n}$ independent loci. Heredity 88: 221-228.

SAMPSON, J. F. (1998): Multiple paternity in Eucalyptus rameliana (Myrtaceae). Heredity 81: 349-355.

SAnTos, C. F. and M. L. AIsy (2012): Interactions between carpenter bees and orchid bees (Hymenoptera: Apidae) in flowers of Bertholletia excelsa Bonpl. (Lecythidaceae). Acta Amazonica 42: 84-94.

Sebbenn, A. M. (2006): Sistema de reprodução em espécies arbóreas tropicais e suas implicações para a seleção de árvores matrizes para reflorestamentos ambientais. In: HigA, A. R. and L. D. Silva. Pomares de sementes de espécies florestais nativas. Curitiba: FUPEF, p. 93-138.

Silva, C. R. S., P. S. B. Albuquerque, F. R. ErveDosa, J. W. S. Mota, A. Figueira and A. M. SEBBENN (2011): Understanding the genetic diversity, spatial genetic structure and mating system at the hierarchical levels of fruits and individuals of a continuous Theobroma cacao population from the Brazilian Amazon. Heredity 106: 973-985.

SuJII, P. S., P. W. Inglis, A.Y. Ciampi, V. N. Solferini and V. C. R. AzEvedo (2013): Isolation and characterization of microsatellite markers for Bertholletia excelsa (Lecythidaceae) population genetic analysis. Genet. Mol. Res. 12: 5278-5282.

Sujit, P. S., K. Martins, L. H. O. Wadt, V. C. R. Azevedo and V. N. Solferini (2015): Genetic structure of Bertholletia excelsa populations from the Amazon at different spatial scales. Conserv. Genet. DOI 10.1007/s10592-015-0714-4.

Surles, S. E., J. Arnold, A. Schabel, J. L. HAMrick and B. C. BongARTEN (1990): Genetic relatedness in open pollinated families of two leguminous tree species, Robinia pseudoacacia L. and Gleditsia triacanthos L. Theor. Appl. Genet. 80: 49-56.

Tambarussi, E. V., D. Boshier, R. Vencovsky, M. L. M. Freitas and A. M. Sebbenn (2015): Paternity analysis reveals significant isolation and near neighbour pollen dispersal in small Cariniana legalis Mart. Kuntze populations in the Brazilian Atlantic Forest. Ecology and Evolution. doi: 10.1002/ece3.1816

WAdt, L. H. O., K. A. Kainer and D. A. P. GomesSILvA (2005): Population structure and nut yield of a Bertholletia excelsa stand in Southwestern Amazonia. Forest Ecology and Management 211: 371384.

Wadt, L. H. O., K. A. Kainer, C. Staudhammer and R. SERRENo (2008): Sustainable forest use in Brazilian extractive reserves: Natural regeneration of Brazil nut in exploited populations. Biological Conservation 141: 332-346.

WARD, M., C. W. Dick, R. Gribel and A. J. Lowe (2005): To self, or not to self... A review of outcrossing and pollen-mediated gene flow in Neotropical trees. Heredity 95: 246-254.

\title{
PCR-based detection of single sequence variants from a natural collection of the non-model tree species European Aspen Populus tremula (L.)
}

\author{
By S. WinkleR ${ }^{1)}$, K. Linke ${ }^{2)}$, N. GscheideL ${ }^{1)}$, M. MeYeR ${ }^{2)}$ and D. KrabeL ${ }^{2), *)}$
}

(Received $11^{\text {th }}$ November 2015)

\begin{abstract}
In the present study we present and discuss the identification of species-specific SNPs to

1) MPI of Molecular Cell Biology and Genetics, DNA Sequencing Facility, Pfotenhauerstr. 108, D-01307 Dresden, Germany.

$\left.{ }^{2}\right)$ Molecular Physiology of Woody Plants Group, Dresden University of Technology, Pienner Str. 7, D-01737 Tharandt, Germany.

*) Corresponding author: DoRIS KRABEL.

E-Mail: krabel@forst.tu-dresden.de
\end{abstract}

rule out any experimental influence of speciesspecific primer design (Populus tremula vs. the closely related model-species Populus trichocarpa) on the detectability of SNPs. Applying a species-optimized method, partial sequences of 14 genes involved in xylem cell development, xylogenesis, pectin formation, and drought stress reaction were analyzed at the genomic level. About $3 \mathrm{Mb}$ of sequence information were generated by Sanger sequencing technology and 258 sequence variants were 